\title{
PENERAPAN PEMBELAJARAN KOOPERATIF TIPE STAD UNTUK MENINGKATKAN AKTIVITAS BELAJAR DAN HASIL BELAJAR ILMU KIMIA SISWA SMAN 1 NATAR LAMPUNG SELATAN Dwi Yulianti
}

Fakultas Keguruan dan Ilmu Pendidikan Universitas Lampung

\begin{abstract}
Abtrak : Tujuan penelitian ini adalah untuk membelajarkan siswa dengan pembelajaran kooperatif tipe STAD guna meningkatkan aktivitas belajar siswa, hasil belajar kognitif siswa, dan persentase jumlah siswa yang mendapat skor hasil belajar di atas 64 siswa kelas X.2 dan X.3 di SMAN 1 Natar Lampung Selatan. Untuk mencapai tujuan penelitian dilakukan penelitian tindakan kelas pada kelas X.2 dan X.3 di SMAN 1 Natar Lampung Selatan. Penelitian dilakukan sebanyak tiga siklus pada tahun pembelajaran 2005/2006. Tahap-tahap tindakan yang dilakukan pada setiap siklus dimulai dari: 1) tahap perencanaan tindakan, 2) tahap pelaksanaan tindakan dan observasi, 3) evaluasi, dan 4) refleksi. Indikator keberhasilan tindakan adalah: 1) ada peningkatan aktivitas belajar sebesar 5 persen, 2) ada peningkatan rerata hasil belajar kognitif sebesar 5 angka (skor) dibandingkan dengan hasil belajar kognitif pada siklus sebelumnya, dan 3) ada peningkatan persentase jumlah siswa yang memperoleh skor di atas 64, sebesar minimal 5 persen dari siklus ke siklus. Berdasarkan hasil analisis data diketahui bahwa: 1) peningkatan aktivitas belajar dari siklus satu ke siklus dua berada antara 2,76\% sampai 10,71\%, dan peningkatan aktivitas belajar dari siklus dua ke siklus tiga berada antara $0,21 \%$ sampai $4,48 \%, 2$ ) peningkatan rerata skor hasil belajar dari siklus 1 ke siklus 2 sebesar 6,39 angka, dan peningkatan rerata skor hasil belajar dari siklus 2 ke siklus 3 sebesar 6,29, dan 3) peningkatan persentase siswa yang memperoleh skor $>64$ dari siklus satu ke siklus dua sebesar $6,06 \%$, dan peningkatan persentase siswa yang memperoleh skor $>64$ dari siklus dua ke siklus tiga sebesar $8,85 \%$. Kesimpulan penelitian ini adalah bahwa pembelajaran kooperatif tipe STAD dapat meningkatkan aktivitas belajar siswa, meningkatkan hasil belajar kognitif siswa, dan sekaligus meningkatkan persentase jumlah siswa yang mendapat skor hasil belajar di atas 64 siswa kelas X.2 dan X.3 di SMAN 1 Natar Lampung Selatan.
\end{abstract}

Kata kunci : strategi mengajar, pembelajaran kooperatif, penelitian tindakan kelas, hasil belajar

Abstract : The purpose of this study is to facilitate students to learn with the STAD type of cooperative learning in order to improve students' learning activities, enhance students' cognitive achievements, and increase the percentage of students who obtained a score above 64 of students classroom X.2 and X.3 at SMAN 1 Natar South Lampung. To achieve the goals of the research conducted classroom action research on classroom X.2 and X.3 at SMAN 1 Natar South Lampung. Research was conducted for three cycles of the academic year 2005/2006. Stages of the action taken on each cycle starts from: 1) the action planning phase, 2) phase of the implementation of actions and observations, 3) evaluation, and 4) reflection. Indicators were measures of success: 1) an increase of five per cent of learning activities, 2) an increasing cognitive achievements mean of five digits (score) compared with the cognitive achievements in the previous cycle, and 3) an increasing percentage of the number of students who obtained a score above 64 , for a minimum of 5 percent from cycle to cycle. Based on the results of data analysis found that: 1) there was an increased in activity of learning from first cycle to second cycle were between $2.76 \%$ to $10.71 \%$, and an increased in activity cycle of learning from second to third cycles were between $0.21 \%$ to $4.48 \%$, 2) there was an increased in mean score of learning outcome from first cycle to second cycle of 6.39 points, and an improved in mean score of achievements from second cycle to third cycle for 6.29, and 3) there was an increased the percentage of students who obtained a score above 64 from first cycle to second cycles of $6.06 \%$, and an increased the percentage of students obtained a score above 64 from second cycle to third cycles of $8.85 \%$. The conclusion of this study is that type STAD cooperative learning can improved students' learning activities, enhanced students' cognitive achievements, and increased the percentage of students who obtained score above 64 of students achievements at classroom X.2 and X.3 SMAN 1 Natar South Lampung.

Keywords: teaching strategy, cooperative learning, classroom action research, cognitive achievement.

\section{PENDAHULUAN}

Berbagai hasil penelitian baik di dalam negeri maupun di luar negeri menunjukkan siswa mengalami kesulitan untuk membangun pengetahuan kimia secara bermakna. Hal yang sama dialami siswa di SMAN 1 Natar. Berdasarkan hasil observasi awal yang dilakukan pada bulan Nopember 2004 menunjukkan siswa masih mengalami kesulitan untuk mampu membangun pengetahuan kimia secara bermakna.

Menurut Scerri [1] dan MacKinnon [2] ada beberapa factor yang menyebabkan mengapa siswa mengalami kesulitan membangun pengetahuan kimia secara bermakna?, pertama, pengetahuan kimia umumnya abstrak, kedua untuk mampu membangun pengetahuan kimia yang umumnya abstrak dibutuhkan kemampuan berfikir formal, namun kemampuan berfikir formal umumnya belum dimiliki siswa di jenjang SMA. Ini berarti diperlukan solusi untuk mengatasi masalah yang terjadi.

Menurut Reigeluth [3] dan Merril [4] hasil belajar merupakan efek dari kondisi dan metode pembelajaran yang diterapkan. Ini berarti untuk membantu mengatasi masalah yang ada, perlu dipilih dan diterapkan strategi pembelajaran yang tepat guna membantu siswa membangun pengetahuan kimia secara bermakna.

Ada berbagai macam strategi pembelajaran, menurut Slavin [5] dan Arends [6] salah satu macam strategi pembelajaran adalah strategi pembelajaran kooperatif. Pembelajaran kooperatif mampu meningkatkan 
J. Pijar MIPA, Vol. V No.1, Maret : 39 - 42

ISSN 1907-1744

perolehan belajar siswa pada tingkat yang lebih tinggi [5], [6]. Menurut Moore [7] pembelajaran kooperatif memiliki berbagai keunggulan, yaitu memfasilitasi siswa untuk membangun dan mengembangkan kemampuan sosial dan kognitif. Berdasarkan pendapat para ahli mengenai keunggulan pembelajaran kooperatif dan hasil penelitian disimpulkan pembelajaran kooperatif dapat membantu siswa kelas X di SMAN 1 Natar Lampung Selatan untuk memperoleh hasil belajar yang bermakna.

Menurut Arend [6] ada 6 langkah utama dalam menerapkan pembelajaran kooperatif, yaitu 1) penyampaian tujuan pembelajaran, 2) presentasi informasi, 3) pengorganisasian siswa ke dalam tim-tim belajar, 4) membantu kerja tim dan belajar, 5) pengujian berbagai materi atau kelompok-kelompok mempresentasikan hasil-hasil kerjanya, dan 6) pemberian pengakuan atas prestasi dan usaha yang dicapai individu dan kelompok.

Tujuan penelitian ini adalah: 1) untuk membelajarkan siswa dengar pembelajaran kooperatif tipe STAD guna meningkatkan aktivitas belajar pada matapelajaran kimia di kelas X.2 dan X.3 di SMAN 1 Natar Lampung Selatan, 2) untuk membelajarkan siswa dengan pembelajaran kooperatif tipe STAD guna meningkatkan hasil belajar kognitif siswa kelas X.2 dan X.3 di SMAN I Natar lampung Selata, dan 3) membelajarkan siswa dengan pembelajaran kooperatif tipe STAD. guna meningkatkan persentase jumlah siswa yang mendapat skor hasil belajar $>64$.

\section{METODE PENELITIAN \\ 2.1 Desain Penelitian}

Penelitian ini menggunakan rancangan penelitian tindakan kelas. Rancangan penelitian tindakan kelas terdiri dari beberapa siklus, setiap siklus terdiri dari tahapan kegiatan sebagai berikut.

1. Merencanakanan kegiatan yang diharapkan dapat mengatasi masalah yang sedang dihadapi.

2. Melaksanakan kegiatan sebagaimana yang telah direncanakan sebelumnya. Selama melaksanakan tindakan pada subyek penelitian, dilakukan observasi terhadap keterlaksanaan pembelajaran dan belajar.

3. Mengevaluasi perolehan belajar yang terdiri dari mengevaluasi hasil belajar.

4. Merefleksi hasil belajar yang diperoleh dan aktivitas belajar yang ditunjukkan siswa, dengan indikator pembelajaran dan kegiatan membelajarkan yang dilakukan pembelajar. Jika hasil belajar dan aktivitas belajar telah mencapai indikator penelitian maka tindakan pembelajaran dihentikan. Artinya jika hasil belajar dan aktivitas belajar telah mencapai indikator penelitian maka siklus tindakan dihentikan. Namun jika hasil belajar dan aktivitas belajar belum mencapai indikator penelitian, maka tindakan pembelajaran dilanjutkan pada siklus selanjutnya.

Langkah-langkah kegiatan pada siklus berikutnya sama dengan tahapan tindakan pada siklus sebelumnya, yaitu perencanaan, pelaksanaan dan observasi, evaluasi dan refleksi. Perencanaan disusun berdasarkan hasil refleksi pada siklus berikutnya.

\subsection{Subyek Penelitian}

Subyek penelitian ini adalah siswa kelas X.2 dan X.3 SMAN 1 Natar Lampung Selatan tahun pembelajaran 2005-2006. Penetapan subyek penelitian dilakukan berdasarkan kebutuhan akan tindakan pembelajaran guna meningkatakan perolehan belajar kimia dan aktivitas belajar. Jumlah total subyek penelitian adalah sebanyak 79 siswa. Jumlah subyek belajar kelas X.2 adalah sebanyak 39, dan jumalah sabyek belajar kelas X.3 adalah sebanyak 40. Rincian jumlah subyek belajar pada setiap kelas berdasarkan gender disajikan pada Tabel 1.

Tabel 1. Sebaran Jumlah Subyek Belajar Berdasarkan Gender

\begin{tabular}{|l|l|c|c|}
\hline \multirow{2}{*}{ Subyek } & \multicolumn{2}{|c|}{ Jenis Kelamin } & \multirow{2}{*}{ Total } \\
\cline { 2 - 3 } & Pria & Wanita & \\
\hline Kelas X.2 & 15 & 24 & 39 \\
\hline Kelas X.3 & 16 & 24 & 40 \\
\hline Total & 31 & 48 & 79 \\
\hline
\end{tabular}

\subsection{Indikator Pencapaian Penelitian}

Keadaan yang diharapkan setelah dilakukan upaya-upaya dalam bentuk tindakan, melalui penerapan pembelajaran kooparetif adalah sebagai berikut.

1. Ada peningkatan rerata hasil belajar kognitif sebesar 5 angka (skor) dibandingkan dengan hasil belajar kognitif pada siklus sebelumnya. Penilaian menggunakan skala 1-100.

2. Ada peningkatan persentase jumlah siswa yang memperoleh skor di atas 64, sebesar minimal 5 persen dari siklus ke siklus.

3. Ada peningkatan aktivitas belajar sebesar 5 persen.

\subsection{Instrumen Penelitian}

Data yang dibutuhkan pada penelitian ini adalah data hasil belajar kognitif, persentase jumlah siswa yang memperoleh skor di atas 64, dan aktivitas belajar. Data ini kemudian dilihat berdasarkan aktivitas pembelajaran yang dilakukan pembelajar. Untuk memperoleh data ini dibutuhkan instrumen sebagai berikut.

1. Untuk memperoleh data hasil belajar kognitif dan persentase jumlah siswa yang memperoleh skor di atas 64 digunakan instrumen tes hasil belajar. Instrumen tes hasil belajar yang digunakan adalah instrumen tes hasil belajar dalam bentuk essay. Instrumen yang digunakan pada penelitian ini telah dilakukan ujicoba untuk mengetahui tingkat validitas dan reliabilitas. Tingkat validitas dan reliabilitas instrumen yang digunakan pada penelitian ini memiliki tingkat validitas dan reliabilitas yang baik.

2. Untuk memperoleh data aktivitas belajar, digunakan instrumen angket. Dalam bentuk 4 skala Likert.

3. Untuk memperoleh data aktivitas pembelajaran yang dilakukan pembelajar, digunakan instrumen pengamatan dalam bentuk 4 skala Likert, dan instrumen wawancara. Instrumen wawancara digunakan untuk mengetahui kesulitan dan kendala yang dialami guruketika membelajarkan siswa dengan pembelajaran kooperatif. Data aktivitas pembelajaran 
ini dibutuhkan untuk kegiatan refleksi dan penyusunan rencana tindakan pembelajaran pada tahap siklus berikutnya. Data ini tidak digunakan pada indikator keberhasilan penelitian.

\subsection{Analisis Data}

Ada tiga macam analisis pada penelitian ini, yaitu 1) analisis data aktivitas belajar, 2) analisis data rerata hasil belajar dan persentase jumlah siswa yang memperoleh skor hasil belajar di atas 64, dan 3) analisis data kegiatan pembelajaran yang dilakukan pembelajar, dan kendala serta kesulitan yang dialami guruketika membelajarkan siswa dengan pembelajaran kooperatif tipe STAD.

\section{HASIL DAN PEMBAHASAN}

Berdasarkan data hasil belajar diketahui rerata hasil belajar pada siklus 1 adalah sebesar 58,40 dan pada siklus 2 adalah sebesar 64,79 (Tabel 2). Perbandingan data hasil belajar siklus 1 dan 2 menunjukkan terjadi peningkatan skor sebesar 6,39. Peningkatan skor sebesar 6,39 ini menunjukkan bahwa hasil belajar telah mencapai indikator penelitian.

Tabel 2. Perbandingan Data Hasil Belajar Siklus 1 dan 2

\begin{tabular}{|l|c|c|c|c|}
\hline Hasil Belajar & Sikus 1 & Siklus 2 & Perubahan & Indikator \\
\hline Rerata & 58,40 & 64,79 & 6,39 & $\begin{array}{l}\text { Peningkatan } \\
5 \text { angka }\end{array}$ \\
\hline $\begin{array}{l}\text { Persentase } \\
\text { siswa yang } \\
\text { memperoleh } \\
\text { nilai }>64\end{array}$ & 57,19 & 63,25 & 6,06 & $\begin{array}{l}\text { Peningkatan } \\
5 \%\end{array}$ \\
\hline
\end{tabular}

Berdasarkan data jumlah siswa yang memperoleh skor hasil belajar $>64$ pada siklus 1 adalah sebesar $57,19 \%$, dan pada siklus 2 adalah sebesar 63,25\%. Membandingkan data siklus 1 dan 2 menunjukkan terjadi peningkatan jumlah siswa yang memperoleh skor $>64$ sebesar $6,06 \%$. Peningkatan sebesar $6,06 \%$ ini menunjukkan bahwa jumlah siswa yang memperoleh skor hasil belajar $>64$, telah mencapai indikator penelitian.

Rerata hasil belajar pada siklus 2 adalah sebesar 64,79 dan pada siklus 3 adalah sebesar 71,08 (Tabel 3). Membandingkan data hasil belajar siklus 2 dan 3 menunjukkan terjadi peningkatan skor sebesar 6,29. Peningkatan rerata skor sebesar 6,29 ini menunjukkan bahwa hasil belajar telah mencapai indikator penelitian.

Tabel 3. Perbandingan Data Hasil Belajar Siklus 2 dan 3

\begin{tabular}{|l|c|c|c|l|}
\hline Hasil Belajar & Siklus 2 & Siklus 3 & Perubahan & Indikator \\
\hline Rerata & 64,79 & 71,08 & 6,29 & $\begin{array}{l}\text { Peningkatan } \\
5 \text { angka }\end{array}$ \\
\hline $\begin{array}{l}\text { Persentase } \\
\text { siswa yang } \\
\text { memperoleh } \\
\text { nilai }>64\end{array}$ & 63,25 & 72,10 & 8,85 & $\begin{array}{l}\text { Peningkatan } \\
5 \%\end{array}$ \\
\hline
\end{tabular}

Jumlah siswa yang memperoleh skor hasil belajar $>64$ pada siklus 2 adalah sebesar $63,25 \%$, dan pada siklus 3 adalah sebesar 72,10\%. Membandingkan data siklus 2 dan 3 menunjukkan terjadi peningkatan jumlah siswa yang memperoleh skor $>64$ sebesar $8,85 \%$. Peningkatan sebesar $8,85 \%$ ini menunjukkan bahwa jumlah siswa yang memperoleh skor hasil belajar $>64$, telah mencapai indikator penelitian.

Berdasarkan data aktivitas belajar diketahui aktivitas belajar pada siklus 1 berada pada range $7,05 \%$ sampai 14,25\% (Tabel 4). Pada siklus 2 aktivitas belajar berada pada range $9,81 \%$ sampai $22,56 \%$. Membandingkan data aktivitas belajar siklus 1 dan 2 menunjukkan terjadi peningkatan aktivitas belajar sebesar $2,76 \%$ sampai $10,71 \%$. Berdasarkan data persentase peningkatan aktivitas belajar ini disimpulkan, aktivitas belajar ada yang belum mencapai indikator penelitian, dan ada yang telah mencapai indikator penelitian. Aktivitas belajar yang belum mencapai indikator penelitian adalah aktivitas melibatkan seluruh anggota kelompok ketika membuat kesimpulan. Untuk itu pad siklus 3, gurumemberikan bimbingan pada kelompok-kelompok belajar untuk melibatkan seluruh anggota kelompok ketika membuat kesimpulan.

Tabel 4. Perbandingan Data Persentase Aktivitas Belajar Siklus 1 dan 2

\begin{tabular}{|c|c|c|c|c|}
\hline Aktivitas Belajar & Sikus 1 & Siklus 2 & Perubahan & Indikator \\
\hline $\begin{array}{l}\text { Menjawab } \\
\text { Pertanyaan }\end{array}$ & 10,50 & 15,55 & 5,05 & $\begin{array}{c}\text { Peningkatan } \\
5 \%\end{array}$ \\
\hline $\begin{array}{l}\text { Mengajukan } \\
\text { Pertanyaan }\end{array}$ & 11,85 & 22,56 & 10,71 & \\
\hline $\begin{array}{l}\text { Memperhatikan } \\
\text { Pendapat Orang } \\
\text { Lain }\end{array}$ & 14,25 & 19,67 & 5,42 & \\
\hline $\begin{array}{l}\text { Menghargai } \\
\text { Pendapat Orang } \\
\text { Lain }\end{array}$ & 11,35 & 20,25 & 8,90 & \\
\hline $\begin{array}{l}\text { Melibatkan } \\
\text { Seluruh Anggota } \\
\text { Kelompok ketika } \\
\text { Membuat } \\
\text { Kesimpulan }\end{array}$ & 7,05 & 9,81 & 2,76 & \\
\hline
\end{tabular}

Data aktivitas belajar diketahui aktivitas belajar pada siklus 2 berada pada range 9,81\% sampai 22,56\% (Tabel 5). Data aktivitas belajar pada siklus 3 berada pada range $12,83 \%$ sampai $24,15 \%$ Membandingkan data aktivitas belajar siklus 2 dan 3 menunjukkan terjadi peningkatan aktivitas belajar sebesar $0,21 \%$ sampai $4,48 \%$. Berdasarkan data persentase peningkatan aktivitas belajar ini disimpulkan, aktivitas belajar belum mencapai indikator penelitian, Namun jika membandingkan data persentase aktivitas belajar dari siklus 1 sampai siklus 3, maka peningkatan persentase aktivitas belajar telah mencapai indikator penelitian, karena range persentase peningkatan aktivitas belajar bergerak dari 5,78\% sampai $11,34 \%$. 
J. Pijar MIPA, Vol. V No.1, Maret : 39 - 42

ISSN 1907-1744

Tabel 5. Perbandingan Data Persentase Aktivitas Belajar Siklus 2 dan 3

\begin{tabular}{|c|c|c|c|c|}
\hline Aktivitas Belajar & Sikus 2 & Sikus 3 & Perubahan & Indikator \\
\hline $\begin{array}{l}\text { Menjawab } \\
\text { Pertanyaan }\end{array}$ & 15,55 & 15,76 & 0,21 & $\begin{array}{c}\text { Peningkatan } \\
5 \%\end{array}$ \\
\hline $\begin{array}{l}\text { Mengajukan } \\
\text { Pertanyaan }\end{array}$ & 22,56 & 23,19 & 0,63 & \\
\hline $\begin{array}{l}\text { Memperhatikan } \\
\text { Pendapat Orang } \\
\text { Lain }\end{array}$ & 19,67 & 24,15 & 4,48 & \\
\hline $\begin{array}{l}\text { Menghargai } \\
\text { Pendapat Orang } \\
\text { Lain }\end{array}$ & 20,25 & 21,28 & 1,03 & \\
\hline $\begin{array}{l}\text { Melibatkan Seluruh } \\
\text { Anggota Kelompok } \\
\text { ketikaMembuat } \\
\text { Kesimpulan }\end{array}$ & 9,81 & 12,83 & 3,02 & \\
\hline
\end{tabular}

Hasil penelitian ini mendukung hasil penelitian yang telah dilakukan sebelumnya pada pembelajaran ilmu pengetahuan alam. Hasil penelitian [8], [9], [10] menunjukkan bahwa pembelajaran kooperatif tipe STAD dapat meningkatkan perolehan belajar dan aktivitas belajar pada berbagai mata pelajaran dan pada berbagai jenjang sekolah.

Pembelajaran kooperatif tipe STAD dapat meningkatkan hasil belajar dan aktivitas belajar. Hal ini disebabkan faktor-faktor yang harus ada dalam membelajarkan belajar dengan pembelajaran kooperatif terpenuhi. Faktor-faktor yang ada ketika membelajarkan siswa dengan pembelajaran kooperatif tipe STAD adalah, adanya saling ketergantungan yang positif antara siswa dalam kelompok-kelompok belajar. Saling ketergantungan yang positif yang tercipta dalam pembelajaran kooperatif tipe STAD, akan menyebabkan terjalinya interaksi sosial dan emosional. Interaksi ini akan membangun dan mengembangkan sikap saling membutuhkan. Sikap saling membutuhkan yang dimaksud adalah saling membutuhkan untuk saling membelajarkan, menghargai pendapat orang lain, empati atas kesulitan belajar yang dialami anggota kelompok belajar. Kondisi belajar yang demikian akan meningkatkan aktivitas dan hasil belajar setiap siswa.

Berdasarkan hasil penelitian sebelumnya [5], [11], [12]), pembelajaran kooperatif tipe STAD dapat meningkatkan aktivitas belajar dan hasil belajar karena desain pembelajaran kooperatif menurunkan tingkat kecemasan belajar. Penurunan tingkat kecemasan berpengaruh pada peningkatan hasil belajar dan aktivitas belajar.

\section{KESIMPULAN}

Hasil-hasil penelitian dirangkum sebagai berikut:

1. Faktor saling ketergantungan yang positif yang tumbuh dalam diri setiap anggota kelompok belajar.akan meningkatkan aktivitas belajar, hasil belajar dan jumlah siswa yang memperoleh skor $>64$

2. Bimbingan belajar pada setiap kelompok-kelompok belajar kooperatif, akan memberi arahan pada kelompok-kelompok belajar guna mencapai tujuan belajar yaitu peningkatan hasil belajar, peningkatan aktivitas belajar dan peningkatan jumlah siswa yang memperoleh skor hasil belajar $>64$.

\section{DAFTAR PUSTAKA}

[1] Scerri, E.R. 2003. Philosophical Confusion in Chemical Education Research. Journal of Chemical Education. 80 (5): 468-473.

[2] MacKinnon, G.R. 2004. Why Models Sometimes Fail: Eight suggestions to improve science instruction. Journal of Collge Science Teacher. 32 (7): 430-435.

[3] Reigeluth, C.M (Ed). 1983. Instructional Design Theories and Models. New Jersey: Lawrence Erlbaum Associates.

[4] Merril, M.D (Ed). 1983. Component Display Theory. New Jersey: Lawrence Erlbaum Associates.

[5] Slavin, R.E. 1997. Educational Psychology Theory and Practice (5rd ed). Needham Heights: Allyn and Bacon.

[6] Arends, R.I. 2004. Learning to Teach: Bruner and Discovery Learning. New York: McGraw-Hill.

[7] Moore, K.D. 2005. Effective Instructional Strategies From Theory to Practice. Thousand Oaks: Sage Publications.

[8] Burron, Bruce. James, M Lynn and Ambrosio, Anthony L. 1993. The Effect Of Cooperative Learning In A Physical Science Course For Elementary/ Middle Level Preservice Teachers. Journal of Research In Science Teaching. 7 (30).

[9] Kohn, Alfie. 1991. Don't Spoil The Promise Of Cooperative Learning. Educational Leadership. Virginia: The Association For Supervision And Curriculum Development, 5 (48).

[10] Lonning, Robert A. 1993. Effect Of Cooperative Learning Strategies On Student Verbal Interaction And Achievement During Conceptual Change Instruction In 10 th Glencoe Grade General Science. Journal Of Research In Science Teaching: A. Wiley Interscience Publication, 9 (30).

[11] Jufri. 2000. Keefektifan Pembelajaran Kooperatif. Tesis. Tidak Diterbitkan. Malang: Program Pascasarjana.

[12] Lord,Thomas. 1998. Cooperative Learning That Really Works In Biology Teaching. The American Biologi Teacher . 60 (8) 